\title{
Combating Human Trafficking at the Local Level: Better Informing (Inter)national Action Plans
}

\author{
John Winterdyk ${ }^{* 1}$ \\ Department of Economics, Justice, and Policy Studies, Mount Royal University, Calgary, Alberta, Canada \\ ${ }^{\star}$ Corresponding Author: John Winterdyk, Department of Economics, Justice, and Policy Studies, \\ Mount Royal University, Calgary, Alberta, Canada. E-mail: jwinterdyk@mtroyal.ca
}

(Submitted 2 July 2017; revised 10 October 2017; accepted 9 December 2017; first published online 27 February 2018)

\begin{abstract}
Despite increasing awareness of human trafficking in Canada (and internationally), there is limited knowledge about how local communities are responding to the experiences of trafficked persons. By focusing on the case of counter-trafficking responses in a major city in western Canada, this project represents the first Canadian attempt to document how a major urban centre is addressing human trafficking. The exploratory project surveyed 53 respondents representing agencies involved in the counter-trafficking response, which in various capacities serve individuals victimized by trafficking. Building on the survey findings, five focus group discussions were also conducted. The article suggests that, while a criminal justice framework is important for addressing human trafficking, local strategies will benefit from an emphasis on cross-sector collaboration that emphasizes the rights of the trafficked persons above the needs of law enforcement. Implications for (inter)national responses are also presented.
\end{abstract}

Keywords human trafficking; anti-trafficking; exploitation; criminal justice system; victim assistance

Human trafficking - what some refer to as "modern-day slavery" (Bales 1999; Kara 2009) - has been described as the second most profitable organized criminal activity in the world. While evidence to support this and other claims about the prevalence of human trafficking remains controversial (see Barrett 2011; Jordan and Burke 2011), trafficking has received significant attention from academics, policy makers and advocates, both internationally (for example, Kempadoo 2005; Shelley 2010; Lee 2011) and in Canada (see, for example, Bruckert and Parent 2002; OxmanMartinez, Lacroix, and Hanley 2005; Ogrodnik 2010; Perrin 2010a). Yet, there is still little consensus about the nature, extent or definition of human trafficking, which at

\footnotetext{
${ }^{1}$ An earlier version of this paper was published in the Canadian Journal of Criminology and Criminal Justice (Kaye, Winterdyk, and Quarterman 2014). 
various times has been understood as, and often conflated with, prostitution, labour exploitation, irregular migration and transnational crime (Sanghera 2005). Since the adoption of the United Nations Protocol to Prevent, Suppress and Punish Trafficking in Persons, especially Women and Children in 2000 (Palermo Protocol) (United Nations 2000), international definitions of human trafficking emphasize human trafficking as a form of transnational crime, resulting in counter-trafficking initiatives that focus on restrictive border controls and immigration policies (for example, Jordan 2002; Kempadoo 2005; Lee 2011). However, such anti-trafficking responses have struggled to successfully prosecute perpetrators as well as protect the rights of trafficked persons (Dottridge 2007; Lee 2011; Milivojevic and Segrave 2012; Mishra 2015).

The fundamental rights afforded to all human beings outlined in the United Nations Universal Declaration of Human Rights (United Nations n.d.) offer some protection to trafficked persons, such as the right to freedom from slavery and servitude, freedom of movement, and freedom from inhuman or degrading treatment (see Lee 2011; Burke 2013). Through this declaration and that of the Council of Europe Convention on Action against Trafficking in Human Beings (Council of Europe 2005), human trafficking has been a violation of human rights. Nonetheless, mandatory provisions to protect and assist individuals victimized by human trafficking were absent from the Palermo Protocol (Jordan 2002; Burke 2013). Thus, building on the international definition, Canada ratified the protocol by establishing crime-focused response mechanisms (for example, enhanced border security, immigration controls and initiatives driven by law enforcement), yet paid limited attention to the development of provisions to address the rights and experiences of trafficked persons.

In Canada, there is a widespread belief that both internal and international forms of human trafficking are occurring within and across Canadian borders (Bruckert and Parent 2002; Oxman-Martinez et al. 2005; Perrin 2010a). However, from a criminal justice standpoint, there have only been a handful of successful charges laid and fewer convictions since the inclusion of human trafficking legislation in the Criminal Code in 2005 (Government of Canada 2017). Yet, despite a legally untested definition and a limited number of criminal cases, law enforcement and criminal justice actors have largely shaped discussions of human trafficking and responses to trafficking in Canada (Royal Canadian Mounted Police (RCMP) 2010). In a context where the law remains relatively untested, yet the response emphasizes criminal-justice approaches, the actual experiences of trafficked persons remain unclear and poorly defined.

To help clarify understandings of human trafficking within a localized context, this article explores the patterns and trends of human trafficking in a major city in western Canada, and specifically examines how front-line workers perceive human trafficking and the existing counter-trafficking response.

This article comprises six main sections. The first section briefly engages with the literature on human trafficking and responses to trafficking in Canada. The second section outlines the methodology underlying the findings. The third and fourth sections highlight some of our key findings, including the identified patterns and trends and the problem of overreliance on criminal justice response models. The fifth section will extend the findings into a broader international context and discuss how the present findings might be used to inform action plans in other jurisdictions. The sixth section offers a brief discussion for responding to human trafficking at a local, regional and (inter) national level. In the final section, attention will shift to offering several recommendations, as well as present a prospective research agenda for future analysis. 


\section{HUMAN TRAFFICKING AND RESPONSES TO TRAFFICKING IN CANADA}

Canada is known as a source, transit and destination country for human trafficking (Bruckert and Parent 2002; Perrin 2010a; United States Department of State 2012; RCMP 2014; Government of Canada 2017), where men, women and children are trafficked for the purposes of sexual exploitation and/or forced labour. To identify the national trends of human trafficking, the RCMP released the findings of a threat assessment that examined cases and intelligence between 2005 and 2009 (RCMP 2010). The assessment found that, while men, women and children are trafficked in Canada, women represent many identified trafficked persons and are trafficked primarily for sexual exploitation. However, more recently, cases involving trafficking for the purposes of forced labour are being detected (see, for example, Lowson 2012; Thompson 2012; Grant 2016; Government of Canada 2017). Since new laws to combat human trafficking were introduced in 2005 there have only been 35 related convictions even though well over 125 people have been charged with related offences (Moore and Levasseur 2014). In these cases, police have faced significant barriers to obtaining cooperation from victimized individuals, especially since the individual often faces real and perceived risks of job loss and/or deportation if he or she cooperates (Faraday 2012). These dismal findings unfortunately are not limited to Canada. As Mishra (2015) among others have reported, prosecution of human trafficking cases represents a major challenge for criminal justice systems internationally; this is despite the efforts of many jurisdictions to include provisions to prosecute perpetrators of human trafficking.

As stated by the National Action Plan to Combat Human Trafficking, socially and economically disadvantaged persons - especially some First Nations women, youth and children, as well as migrants and new immigrants, street-involved youth, children in protective services, and new arrivals to large urban centres - are considered "at risk" of being trafficked (Government of Canada 2017). Some evidence suggests that First Nations women are specifically targeted for trafficking for purposes of sexual exploitation (see Oxman-Martinez et al. 2005; Moore and Levasseur 2014), including trafficking by gangs (see Sikka 2009) and exploitation during the migratory movements from First Nations reserves to cities in search of education, employment, or other opportunities depicted in media portrayals and anecdotal descriptions of city life (Oxman-Martinez et al. 2005; Sethi 2007). In these and other cases, socioeconomic marginalization increases vulnerability to human trafficking (see United Nations Office on Drugs and Crime 2011; Quayson and Arhin 2012; Burke 2013).

Canada was among the first countries to ratify the Palermo Protocols ${ }^{2}$ by enacting two pieces of anti-trafficking legislation. The first is section 118 of the Immigration and Refugee Protection Act (IRPA). This section only covers international human trafficking, referring specifically to cases that involved crossing the border into Canada.

In 2005, section 279.01 was incorporated into the Canadian Criminal Code. In addition, section 279.011 criminalizes the trafficking of a person under the age of 18 years. Further, sections 279.02 and 279.03 criminalize the material benefit gained from

\footnotetext{
${ }^{2}$ The Palermo protocols are three supplements to the 2000 Convention against Transnational Organized Crime (the Palermo Convention) adopted by the United Nations. They are: the Protocol to Prevent, Suppress and Punish Trafficking in Persons, especially Women and Children; the Protocol against the Smuggling of Migrants by Land, Sea and Air; and the Protocol against the Illicit Manufacturing and Trafficking in Firearms, Their Parts and Components and Ammunition.
} 
trafficking in persons and withholding or destroying documents for the purpose of human trafficking. Finally, section 279.04 defines the concept of exploitation in human trafficking cases. However, the definition of exploitation has proved problematic for obtaining human trafficking convictions. The onus has been on the individual victimized by trafficking to demonstrate their belief that their safety was threatened. However, trafficked persons do not always wish or are not always able to cooperate with official agencies, given the potential consequences of giving evidence against a trafficker (for example, possible job loss, deportation, threats against family members, etc.). In this way, the very nature of the human trafficking abuse (for example, deception or coercion) can create challenges that prevent trafficked people from considering themselves as victims of crime. In these instances, respect for autonomy can be violated by responses that link "victim" cooperation to service provision or prioritize the prosecution of perpetrators above the rights of trafficked persons.

Despite the adoption of legal mechanisms, Canada has faced major challenges when prosecuting human traffickers. As of December 2014, there have been fewer than 40 human trafficking convictions under the Criminal Code.

In response to significant gaps in the protection of trafficked persons in Canada, in May 2006, Citizenship and Immigration Canada (CIC) adopted a policy to enable trafficked persons to secure immigration status by providing a Temporary Resident Permit (TRP). Initially for up to 180 days, TRPs offer legal immigration status to international trafficked persons identified in Canada and can be extended at the discretion of CIC (CIC 2009). During this time, trafficked persons can obtain access to health care and other services (such as trauma counselling and work permits). While CIC considers whether the person can assist law enforcement in criminal proceedings, the policy clearly states, "victims of trafficking are not required to assist in any criminal investigation or testify against their trafficker to gain temporary or permanent resident status" (Department of Justice 2016). Despite the stated TRP policy, an overreliance on criminal definitions of human trafficking has created barriers for trafficked persons to access TRPs. Therefore, it is important to explore alternatives to the conventional criminal justice response mechanisms.

\section{METHODOLOGY}

Given the complexity and diversity of experiences represented by the single concept of human trafficking, this exploratory study adopts a mixed-method approach, including a survey and facilitated focus group discussions. The sampling procedure for this research was designed to draw on the existing response mechanism in a major city in western Canada. Consequently, a range of agencies and front-line workers providing services to trafficked persons or populations considered vulnerable to human trafficking (for example, agencies serving immigrants, sexual assault centres and youth drop-in centres) were the focus of recruitment efforts for participation in the study. Each of the participants self-identified as being directly involved in the counter-trafficking response and the final sample included government officials, law enforcement personnel, non-government organizations and other social service agencies.

Based on the sampling criteria, a link to an online survey of 28 questions was sent to a total of 94 individuals. The survey questions were designed to gather information about the organizations represented by the respondents as well as their knowledge of human trafficking, their experience working on cases of human trafficking (including 
details of the cases they identified) and their perceptions of the existing response to human trafficking in the city. The survey questions were also designed to inform the focus group portion of the research. In total, 53 survey responses were received, representing a response rate of $56.4 \%$.

Focus group discussions offered survey respondents the opportunity to expand on their responses to the survey questions and to build on the information collected through the survey data. Five focus group sessions were held with a total of 18 representatives. ${ }^{3}$ Due to the diverse composition of each focus group, the discussions took different paths, and participants were encouraged to contribute from their areas of expertise and speak on behalf of their current position and agency as well as considering their previous experience and knowledge.

\section{PATTERNS AND TRENDS OF HUMAN TRAFFICKING}

Given the exploratory and predominantly qualitative nature of the data, it is not possible to state with confidence that certain types of trafficking or the victimization of individuals from a specific demographic is more common or prevalent in the city being the focus of the study. Rather than identify specific numbers of trafficked persons in the city, the present research provides a detailed picture of the perceptions of front-line workers to the existing response.

According to the survey respondents and focus group participants, instances of trafficking for labour and sexual exploitation, involving both foreign nationals and Canadian citizens, occur in the city (see Table 1). In a context where there have been no criminal convictions for human trafficking, it is notable that $44.4 \%$ of respondents indicated that they believed they had encountered one or more cases of human trafficking.

Of the survey respondents who indicated they had encountered one or more trafficked persons, 18 had encountered internal cases of trafficking and 11 had encountered international cases. This is contrary to many media, academic and policy discourses that focus on international forms of trafficking.

In terms of internal forms of human trafficking, respondents identified Aboriginal persons as an over-represented group among individuals victimized by trafficking primarily for the purposes of sexual exploitation. ${ }^{4}$ Trafficking of Aboriginal persons was also a key theme mentioned during focus group discussions. There was a desire to understand how human trafficking affects or includes Aboriginal communities, especially populations living on First Nations reserves. As one front-line service provider suggested, participants were particularly concerned with the limited training and awareness available:

I think the individuals coming to the city from the reserves, a lot more awareness needs to be brought to the Aboriginal community ... but I think that you have to be very culturally sensitive in terms of going to the reserve, in how someone would present this information; it's their youth.

\footnotetext{
${ }^{3}$ When possible, the focus groups were organized by sector (for example, government and law enforcement, non-government and service provision, etc.). However, due to scheduling constraints, many of the focus groups included a cross-sector mix, which, in the end, led to some interesting cross-sector dialogue and information sharing.

${ }^{4}$ Other frequently mentioned demographic details of identified cases of trafficking included female children, female adults, and both Canadian and non-Canadian citizens.
} 
Table 1. To your knowledge, has your group or agency come into contact with trafficked persons?

\begin{tabular}{lcc} 
& Number of survey responses & Proportion of survey responses (\%) \\
\hline Yes & 24 & 44.4 \\
\hline Maybe & 9 & 16.7 \\
\hline No & 13 & 24.1 \\
\hline Don't know & 8 & 14.8 \\
\hline
\end{tabular}

Despite such an expressed desire for more awareness and culturally based education, there is very little research on First Nations' experiences of human trafficking.

The characteristics of identified trafficked persons in the city being studied were varied. While participants described popular stereotypes of trafficked individuals as young, female and Asian, trafficked for forced prostitution, their experiences working with trafficked persons deviated from such stereotypes. Specifically, responses varied about whether or not the majority of trafficked persons in the city are male or female; yet there was general agreement that those trafficked for labour exploitation were typically male (with the exception of domestic servitude) and those trafficked for sexual exploitation were typically female.

Although there was no conclusive data that determined if there were more cases of trafficking for the purposes of labour, sexual or other forms of exploitation, some focus group participants suggested, despite popular images of trafficking, that labour trafficking is more prevalent in international cases of human trafficking:

It was posed to us that human trafficking was explicitly embedded in our communities ... and it was incredibly prolific, a huge problem, and so as an enforcement unit we could either take that and just go investigate, but we didn't have anything to investigate. So, strategically, we determined that what we would do is assess whether that was a true statement - whether human trafficking is to the extent that it's being reported to be. And we focused mainly on two categories, of course, labour and sexual exploitation, and international because that's our mandate. What we're seeing is - although there's a propensity to sort of gravitate or be drawn to the sexual exploitation component ... we're seeing, in terms of minor complaints to actually fully blown investigations and charges - it's on the labour [side]. (Law Enforcement Representative)

As this excerpt suggests, the prevalence and form of human trafficking identified from a law-enforcement standpoint differ from a service provision perspective. Meanwhile, both perceptions diverge from sensational campaigns to raise awareness that predominantly emphasize the sexual exploitation of women. Rather, the research confirmed that front-line workers in the city have encountered trafficked individuals exploited for labour, including domestic servitude as well as forced labour exploitation in the construction, farming and service industries.

Another trend identified by the survey and the focus group respondents was the use of legal immigration channels to facilitate human trafficking and other forms of exploitation throughout the province. In particular, temporary foreign worker (TFW) programmes for lower-skilled workers, including the Live-in Caregiver Program, were 
used to facilitate legal entry into Canada. However, once in Canada, some workers involved in these programmes have been subject to exploitation by their employers (see McCrae 2016). Examples of such treatment include poor or unsafe working conditions, the withholding of passports or identity documents, confinement in warehouses, and the repayment of debts through forced work (known as debt bondage) (also see Bruckert and Parent 2002; Perrin 2010b; Hastie 2012). In these cases, the trafficked persons deviate from stereotypical images because they are legitimate migrant workers with legal immigration status in Canada. Yet, as participants argued, lack of familiarity with the laws that govern labour standards and the ambiguous relationship between human trafficking and labour exploitation have created challenges for identifying and responding to experiences of human trafficking in the province.

While the above data cannot be interpreted as a reflection of the number of trafficked persons in the city being the focus of the study, they do offer useful insight into how front-line workers understand the trends and patterns of human trafficking in general. They can also be used to inform existing responses to the experiences of trafficked persons. Building on this understanding, we now turn to two key factors that have served to limit existing counter-trafficking measures: definitional challenges and an overreliance on criminal justice responses.

\section{HUMAN TRAFFICKING DEFINITIONS: IMPEDING COUNTER-TRAFFICKING INITIATIVES}

Trafficking discourse has been plagued by the proliferation of inaccurate information and confusion over what constitutes human trafficking (see, for example, Salt and Hogarth 2000; Kempadoo 2005; Dottridge 2007; Segrave, Milivojevic, and Pickering 2009; Doezema 2010; Barrett 2011; Jordan and Burke 2011; Mishra 2015; Aronowitz 2017). In turn, ambiguous definitions have impeded the development of effective counter-trafficking responses. In this context, it is unsurprising that participants in this study expressed general confusion surrounding the relationship between legal definitions of human trafficking and other forms of exploitation and abuse. Participants similarly cited definitional challenges, including clear misunderstandings of the existing legal definitions in Canada, as hindrances to identifying and responding to human trafficking. Such definitional challenges further point to the need to conceptualize human trafficking outside a restrictive criminal justice framework.

Focus group discussions revealed that overemphasizing images of victimized women in the sex trade has restricted law enforcement, service providers and the public from accurately identifying and understanding the lived experiences of trafficked persons. In the words of one social service provider:

It's easy to ignore, if you believe [human trafficking] is one thing and then you come into contact with someone [and] if you had the correct information, red flags would be going up, but you're thinking, "No, it has to be this. This is what it is." You're missing potential people who are at risk.

In this way, sensationalized images of an "ideal victim," while possibly helping to raise public awareness, can prevent realistic understandings and result in overlooking certain types of experiences as forms of victimization. Overemphasizing sensational images of human trafficking specifically resulted in individuals trafficked or exploited through legal programmes - such as the TFW programmes for lower-skilled 
workers - being overlooked as possible trafficked persons (also, see McCrae 2016). As the following excerpt from a front-line service provider highlighted, the distinction between labour exploitation and human trafficking remains unclear:

The foreign workers, some of them are not really trafficked per se, they came legally, but when they get exploited, sometimes I find it hard to connect human trafficking because the foreign workers they might not have been trafficked in the definition of human trafficking but they are just as exploited as the ones who were trafficked ... There is a gray area there for me because when someone is exploited, like if they are not being paid, the contract is not being adhered to, it could be an employment standards issue and maybe there is abuse as well, which is a human rights violation ... So with the foreign workers, it doesn't start with transit, it starts here, they come here and everything is legal.

Although human trafficking charges and a related conviction have occurred in a case involving the exploitation of TFWs throughout Canada, the ambiguous relationship between labour standards, labour exploitation and human trafficking has created challenges around accessing services for victimized foreign nationals.

Despite requiring similar services to those of a trafficked person, individuals classified as experiencing forms of labour exploitation that fall outside the realm of human trafficking investigation have been unable to access services. In the words of a frontline service provider,

Foreign workers have really limited access to resources. So, if a foreign worker resigns from their job, then their work permit is also cut off. So, once they are identified as victims of trafficking they will eventually be given a TRP but, you know, for some people who are not found to be victims of that have very limited options.

As this excerpt suggests, when people enter Canada through TFW programmes and experience coercion, deceit or exploitation, they require support and assistance, irrespective of whether enforcement agencies are pursuing charges of a human trafficking offence or not. These experiences are especially problematic because individuals trafficked through legal government programmes may be overlooked by government agencies, such as the Canada Border Services Agency or the CIC that issues TRPs, which are an important tool of support for international trafficked persons. According to the survey participants, this potential oversight occurs because many agencies, both governmental and non-governmental, are unclear on the definition of human trafficking or how to interpret and apply the legal definition of trafficking in Canada's Criminal Code or IRPA. Thus, law enforcement agencies identified the Criminal Code definition of trafficking as particularly onerous and narrow when it comes to laying human trafficking charges, and this, if the definition is universally applied, has created significant gaps in the service provision model.

\section{BEYOND LEGAL DEFINITIONS AND CRIMINAL JUSTICE RESPONSES}

In addition to sensationalized images of trafficked persons, participants identified as problematic an overreliance on the legal definition of trafficking. As one law enforcement officer highlighted: "If you look at human trafficking, by anyone's definition ... there's probably about 25 things that could, sort of, fit into that human trafficking definition." This participant further stated that there were approximately 50 active cases that involve 
some component of human trafficking, yet only 15 that met the threshold of the legal definition. 5 Thus, in a context where human trafficking responses are being developed predominantly from a law enforcement or criminal justice standpoint, some victimized individuals experiencing one or more components of human trafficking - or even cases that meet the legal threshold of trafficking - may not be identified.

Similarly, a government representative highlighted the narrow scope and mandate of law enforcement compared with the breadth and complexity of experiences that potentially fall under human trafficking definitions:

Because we are a law enforcement unit available to government, when we look at these things, I think we're losing some of the picture. We have a certain amount of resources we can deploy in any area, so we are needing to prove our cases to the criminal court standard and therefore we're simply not able to allocate resources to just going out, and just looking at feelers 'cause our mandate is pretty narrow on this pretty broad issue ... There have been cases I've seen where I have some pause, but upon further questioning they just weren't getting there for us to allocate those resources.

As this excerpt suggests, relying on the criminal threshold outlined in the legal definition of trafficking leads to ignoring the varying experiences of trafficked persons that may fall outside the narrow criminal justice mandate and resource allocation. Thus, trafficked persons may not be able to access services that exist, especially services that are tied - explicitly or implicitly - to some form of criminal investigation.

An overreliance on the legal definition is also problematic given some of the general challenges faced by law enforcement and the criminal justice system with laying charges, having the charges move forward, building case law and attaining convictions. One representative of a law enforcement agency discussed the "onerous" nature of the Criminal Code definition:

[The Criminal Code definition] is so unbelievably onerous, unfortunately, so onerous that we can't lay charges to actually create the case law that defines the Criminal Code ... it's horrific. It's one of the first real Catch-22s we've seen in the Criminal Code. You know, assault is easily defined and you can lay those charges, case law defines it, very quickly. This one [human trafficking], it's been on the books for several years and it is almost to the point where investigators are realizing we really can't hit that standard and the prosecutors are very reluctant to try to prosecute on that standard.

This participant went on to share additional detail on why the Criminal Code has proven problematic for law enforcement agencies when pursuing human trafficking charges and prosecutions:

You have to prove a fear, you have to prove that [trafficked persons] were entirely unwilling or there was no real consent component at any point, or maybe if there was consent it's a clear delineation of when that consent stopped, and it's just unbelievably onerous ... And it may continue to be until we either get charges and

${ }^{5}$ This observation is consistent with the issues and concerns raised by various contributors in Savona and Stefanizzi (2010). 
the case law defines it, or Parliament realizes that and starts clipping at it. And ... if you attribute the threshold, for us, there's two thresholds: one, do we have the grounds to charge and then the threshold to actually convict.

This experience of implementing and applying the Criminal Code appears to be in opposition to the actual text of article 2 of section 279.01 that reads, "No consent to the activity that forms the subject matter of a charge under subsection (1) is valid." Nonetheless, this problem has also been identified by other research in the area (see, for example, Perrin 2010a). Regardless, the narrow scope of the legal definition of human trafficking, alongside the resource constraints of law enforcement agencies aiming to meet the criminal threshold of this definition, result in a limited capacity of law enforcement to identify the complex experiences of trafficked persons. Thus, while criminal definitions and responses are key elements of any response model, they should not be the exclusive, or even the dominant, element of the response. Rather, as will be discussed, the experiences of trafficked persons are better served by expanding response models to include government, non-government and criminal justice elements.

Overall, it was suggested that the confusion surrounding the definition of human trafficking has limited effective identification and support of persons victimized by human trafficking or elements of trafficking and has created challenges for pressing criminal charges against traffickers. This highlights the need to examine and accept definitions of human trafficking between and across sectors. As discussed, while law enforcement agencies will require a definition that outlines the threshold of evidence to determine that a crime has been committed, many social service agencies can and will accept a more liberal interpretation of the phenomenon for the purposes of service delivery. Again, this issue is not limited to Canada, but has been commented on within a broader international context (see Mishra 2015).

\section{TOWARDS CROSS-SECTOR COLLABORATION}

Despite the limitations just discussed of approaches that centre on a criminal justice framework and definition, Canada's response to human trafficking is largely driven by the same criminal justice mandate (RCMP 2010; Perrin 2010a; Government of Canada 2017) that is characteristic of how most countries attempt to respond to human trafficking (see Dalla et al. 2011; Aronowitz 2017). While the criminal justice system remains an important aspect of any response model, the present research points to the need to move beyond a strict criminal justice framework when responding to the trafficking of human beings. Even though throughout Canada (in particular the provinces of Alberta and British Columbia) law enforcement, social serving agencies and government have participated in cross-sector information exchanges and ad hoc case management of identified trafficked persons, it was observed in the focus group discussions that there was a need to move cross-sector interactions beyond information sharing to develop a more collaborative response, including protocol agreements, standard operating procedures, and collaborative case consultation and management. Again, similar, but more generalized, observations on an international level have been made by Quayson and Arhin (2012), and by the United States Government Accountability Office in 2007 (United States Government Accountability Office 2007).

As discussed, participants representing government and law enforcement agencies indicated that human trafficking experiences are falling outside the realm of a 
criminal justice response. As one government official declared, "[W]e could be missing a lot of the picture and a lot of them are afraid of government. So, the social agencies are probably getting a bigger picture than the enforcement agencies." Although social services agencies may be best situated to identify the broad-ranging experiences of human trafficking, it is law enforcement and government agencies that have been mandated with key aspects of victim assistance and support. For instance, to access a TRP, trafficked persons are essentially required to report their experiences to law enforcement, and law enforcement is mandated with primary aspects of victim support during the investigative process. However, as one law enforcement representative suggests, the interest of law enforcement centres on investigation and obtaining criminal convictions, goals that are not necessarily in line with the interest or rights of the individual victimized by human trafficking:

The investigative side is unbelievably selfish, and I'd like the two to split, so there's still consult between the support group and the investigative group in terms of the best things for the victim, but the investigative group should not be doing the support piece. It's impacting negatively the prosecution of these cases in terms of time delays, in terms of manpower, and resources. So, I'd like those two things split.

As this excerpt suggests, offering support to trafficked persons is perceived as constraining the limited resources available to law enforcement to investigate and prosecute human trafficking cases. Meanwhile, the support offered to the trafficked individual is connected to the investigative needs of law enforcement, which can be counterproductive to the interests of trafficked persons. This is especially the case in a context, such as Canada, where prosecutions are dependent on the testimony of a "victim" of crime.

Overall, participants pointed to a need to move away from strict legal interpretations of human trafficking to better incorporate the autonomy and rights of trafficked individuals. Participants further perceived a need to support collaborative efforts that made a clear separation between assistance to trafficked persons and the investigation and prosecution of human traffickers. Notwithstanding the importance of such collaboration, it is worth noting that effective collaboration across these sectors can prove challenging, given the unequal resources and capacity that each actor brings to the table. However, even more problematic are occasions when nongovernmental organizations receive government funding that is attached to the mandates of the funding body (see McCrae 2016). Furthermore, as discussed, emphasizing the "victim of crime" status of trafficked persons can limit support, especially in cases of internationally trafficked persons who could benefit from accessing a TRP but who do not wish to report their experiences to government or law enforcement. In this way, discussions of collaboration should not be naïve as to the role of power dynamics, funding sources and the specialized mandates of the organizations involved in the collaboration.

\section{DISCUSSION}

Although the study was exploratory in nature, when comparing the findings with those found in other studies or reports (see, for example, Ezeilo 2014) several international lessons can be posited to better inform local, (inter)national action plans. Guided and informed by international human rights law and standards, these recommendations, while not necessary new, are informed through the evidenced 
informed research and comparative analysis. Regardless of whether an action plan is local or (inter)national, consistent with recommendations by the UNODC any anti-trafficking responses should be based on what is often referred to as the ' $5 \mathrm{Ps}$ ': Protection of victim, Prosecution of perpetrators of the human trafficking, Punishment of the perpetrators, Prevention of human trafficking, promoting local and/or (inter)national cooperation and Partnership. A review of many action plans reveals that many countries have created reasonable protocols for the first four Ps (i.e. protection, prosecution, punishment and prevention) but come up short on the final P - partnership. Yet, as Joy Ngozi Ezeilo who until 2014 was a Special Rapporteur with the UN, pointed out in her remarks that marked the World Day Against Human Trafficking in Persons, the different stakeholders should include "governments, businesses, civil society, organizations and trafficked persons themselves" (Ezeilo 2014:1) when developing their strategic plans. Furthermore, it is important to bear in mind that trafficking in persons is a multi-million-dollar global commerce that is both a domestic and transnational crime and therefore it is critical for any action plan to consider cooperation and participation at all levels - that is, at local, national, sub-regional and international levels. This is an observation that is readily made by numerous national rapporteurs (see, generally, Dandurand 2017).

Related to the 5Ps and supporting the main findings in this study, what is also needed is what has been referred to as the '3Rs': Redress, Recovery and Reintegration, which refer directly to supporting victims of trafficking. Again, as Ezeilo noted at the 2010 United Nations meeting in Bangkok, it is essential to build capacity not only in combating human trafficking but in supporting and addressing the needs of its victims (Ezeilo 2014). At the same meeting, Sriprapha Petcharamesree, from Thailand, highlighted some of the initiatives that were taking place within the Association of Southeast Asian Nations (ASEAN), including with the newly established AICHR (ASEAN intergovernmental Commission on Human Rights). During her presentation, she also stressed the importance of regional and international human rights mechanisms working together to effectively tackle issues such as human trafficking (Human Rights Herald 2010).

Finally, the third and final related component of any action plan for combating human trafficking, and as supported by the findings of this study, is to integrate the 5Ps along with the 3Rs. To do so, we can borrow from the work and ideas of Dandurand (2017) and Ezeilo (2014) and consider the '3Cs' (i.e. Capacity, Cooperation and Coordination). Human trafficking, as is well documented, does not only occur at a local level but it is also a global and transnational crime. Therefore, while this study examined response mechanisms at a local level, in order to effectively combat human trafficking it is necessary, if not critical, to build capacity at all levels. This will require greater cooperation between all levels of government and between governments and nations. And to do so, there is a need to coordinate such actions. Although there are numerous organizations around the world that either combat human trafficking and/ or help victims of trafficking, there is to date no agency or organization that coordinates such initiatives. Therefore, the current soloing of effort fails to produce much return on its investment. Hence, the problem appears to be growing.

\section{CONCLUSION AND FUTURE RESEARCH}

Through an exploratory examination of counter-trafficking responses in a major western Canadian city, Alberta, this article shows that definitional challenges alongside an 
overemphasis on law enforcement and criminal-justice responses have limited the identification of trafficked persons, especially those trafficked and/or exploited through legal entry points into the country, such as individuals arriving through TFW programmes for lower-skilled workers. Further, in examining a localized context, the article suggests that by centring the national response model on restrictive legal definitions of human trafficking and the investigative requirements of law enforcement agents, the existing response strategy limits service provision in the city for trafficked persons and individuals experiencing elements of exploitation related to trafficking. Considering this, it is suggested that there needs to be enhanced cross-sector understandings of human trafficking to account for the narrow investigative needs of law enforcement alongside the broad-ranging services required to address the experiences of trafficked persons. In this way, it becomes important to situate response models outside the limited realm of the criminal justice system by developing cross-sector collaborations whereby government, non-government and law enforcement agencies collaborate to develop and implement localized protocols to respond to human trafficking. However, in doing so, such partnerships require a thorough recognition of the politicized nature of responses to human trafficking and the funding, mandate and power dynamics that shape antitrafficking agendas. For example, despite the fact the slavery/human trafficking dates to ancient times, it was not until 2014 that the United Nations declared July 30th as "World Day against Trafficking in Persons". 6

Overall, the research highlights the need to better understand specific forms of human trafficking, especially the internal trafficking of Aboriginals in Canada and the effects of human trafficking on Aboriginal communities. In addition, the use by traffickers of TFW programmes for lower-skilled workers, as well as the relationship between human trafficking and labour exploitation, requires further examination. Moreover, future analyses may enhance existing knowledge by replicating this study and comparing the findings with findings from other jurisdictions throughout Canada. Thus, this research can inform the development of protocols within other communities and provinces, and other regions of the world that can eventually be used to inform partnerships and collaboration. As the present article demonstrates, localized understandings of human trafficking can contribute to the adoption of more effective national understandings and response strategies to address human trafficking in Canada and elsewhere in the world. To this end, the points raised in the Discussion section above may serve as a focal point. In the end, it must be recognized that we have not only a legal obligation to protect the human rights violations that victims of human trafficking often endure, but we also have a moral obligation to fight human trafficking in whatever form it expresses itself.

\section{References}

Aronowitz, Alexis A. 2017. Human Trafficking: A Reference Handbook. Santa Barbara, CA: ABC-CLIO. Bales, Kevin. 1999. Disposable People: New Slavery in the Global Economy. Berkeley and Los Angeles, CA: University of California Press.

Barrett, Nicole A. 2011. An Exploration of Promising Practices in Response to Human Trafficking in Canada. Vancouver, BC: International Centre for Criminal Law Reform.

\footnotetext{
${ }^{6}$ The author finds it ironic that whenever he conducts presentations on human trafficking (and even to informed groups), very few people can identify on what day, let alone in which month, the occasion is celebrated.
} 
Bruckert, Christine and Colette Parent. 2002. "Trafficking in Human Beings and Organized Crime: A Literature Review." Ottawa: Research and Evaluation Branch, RCMP. Retrieved February 2018 (http:// www.nswp.org/resource/trafficking-human-beings-and-organised-crime-literature-review).

Burke, Mary C. 2013. Human Trafficking: Interdisciplinary Perspectives. New York: Routledge.

Citizenship and Immigration Canada (CIC). 2009. "Protection and Assistance for Victims of Human Trafficking.” Retrieved January 2018 (http://www.cic.gc.ca/english/information/applications/trp.asp).

Council of Europe. 2005. "Council of Europe Convention on Action against Trafficking in Human Beings." 16 May 2005, Council of Europe Treaty Series No. 197. Retrieved January 2018 (https://www.coe.int/en/ web/conventions/full-list/-/conventions/treaty/197).

Dalla, Rochelle L., Lynda M. Baker, John DeFrain, and Celia Williamson (editors). 2011. Global Perspectives on Prostitution and Sex Trafficking. New York: Lexington Books.

Dandurand, Yvon. 2017. "Preventing Violence Against Children: The UN Model Strategies." Pp. 33-64 in Crime Prevention: International Perspective, Issues, and Trends, edited by John Winterdyk. Boca Raton, FL: CRC Press.

Department of Justice. 2016. "Protection and Assistance for Victims of Human Trafficking." Retrieved January 2018 (https://www.canada.ca/en/immigration-refugees-citizenship/services/application/applicationforms-guides/protection-assistance-victims-human-trafficking.html).

Doezema, Jo. 2010. Sex Slaves and Discourse Masters: The Construction of Trafficking. London: Zed Books Ltd.

Dottridge, Mike. 2007. "Introduction." Pp. 1-27 in Collateral Damage: The Impact of Anti-Trafficking Measures on the Human Rights around the World. Bangkok: Global Alliance Against Traffic in Women.

Ezeilo, Joy. 2014. "For World Day Against Trafficking in Person Wednesday 30 July 2014: 'Human Trafficking: Take Action, Break The Chain' - UN Rights Expert.” Retrieved January 2018 (http://www. ohchr.org/en/NewsEvents/Pages/DisplayNews.aspx?NewsID=14906\&LangID=E).

Faraday, Fay. 2012. "Made in Canada: How the Law Constructs Migrant Workers' Insecurity." Metcalf Foundation. Retrieved January 2018 (http://metcalffoundation.com/publications-resources/view/madein-canada/).

Government of Canada. 2017. "National Action Plan to Combat Human Trafficking." Retrieved January 2018 (https://www.publicsafety.gc.ca/cnt/rsrcs/pblctns/ntnl-ctn-pln-cmbt/index-en.aspx).

Grant, Travia. 2016. "Police Find 16 Human-Trafficking Victims in Cross-Canada Investigation." The Globe and Mail, 18th October 2016. Retrieved January 2018 (https://www.theglobeandmail.com/news/national/32charged-with-78-offences-in-canada-wide-human-trafficking-probe-police/article32414033/).

Hastie, Bethany. 2012. "Doing Canada's Dirty Work: A Critical Analysis of Law and Policy to Address Labour Exploitation Trafficking." Pp. 121-37 in Labour Migration, Human Trafficking and Multinational Corporations: The Commodification of Illicit Flows (Routledge Transnational Crime and Corruption), edited by Ato Quayson and Antonela Arhin. New York: Routledge.

Human Rights Herald. 2010. "Human Rights Herald: January 2010.” Retrieved January 2018 (www. aseanhrmech.org/downloads/Human_Rights_Herald_Jan2010_Issue.pdf).

Jordan, Ann. 2002. "Human Rights or Wrongs? The Struggle for a Rights-Based Response to Trafficking in Human Beings." Gender and Development 10(1):28-37.

Jordan, Ann and Lynn Burke. 2011. "Is Human Trafficking Really the Third Most Profitable Business for Organized Crime?” Retrieved January 2018 (http://rightswork.org/research/fact-checker).

Kara, Siddharth. 2009. Sex Trafficking: Inside the Business of Modern Slavery. New York: Columbia University Press.

Kaye, Julie, John Winterdyk, and Lara Quarterman. 2014. "Beyond Criminal Justice: A Case Study of Responding to Human Trafficking in Canada." Canadian Journal of Criminology and Criminal Justice 56(1):23-48.

Kempadoo, Kamala. 2005. "Introduction: From Moral Panic to Global Justice: Changing Perspectives on Trafficking." Pp. vii-xxxiv in Trafficking and Prostitution Reconsidered: New Perspectives on Migration, Sex Work, and Human Rights, edited by Kamala Kempadoo, Jyoti Sanghera and Bandana Pattanaik. Boulder, CO: Paradigm.

Lee, Maggy. 2011. Trafficking and Global Crime Control. London: Sage Publications Ltd.

Lowson, Glenn. 2012. "How Hungarian Criminals Built a Slave Trade in Ontario." The Globe and Mail, 2nd April 2012. Retrieved January 2018 (https://www.theglobeandmail.com/news/national/howhungarian-criminals-built-a-slave-trade-in-ontario/article2390190/). 
McCrae, Karen. 2016. Labour Trafficking in Edmonton: Holding Tight to a Double-Edged Sword. Edmonton, AB: ACT.

Milivojevic, Sanja and Marie Segrave. 2012. "Evaluating Responses to Human Trafficking: A Review of International, Regional, and National Counter-Trafficking Mechanisms." Pp. 233-64 in Human Trafficking: Exploring the International Nature, Concerns, and Complexities, edited by John Winterdyk, Benjamin Perrin and Philip Reichel. Boca Raton, FL: CRC Press.

Mishra, Veerendra. 2015. Combating Human Trafficking: Gaps in Policy and Law. Thousand Oaks, CA: Sage Publications Inc.

Moore, Holly and Joanne Levasseur. 2014. "Human Traffickers Going Unpunished in Canada, Experts Say.” CBCnews. Retrieved January 2018 (http://www.cbc.ca/news/canada/manitoba/human-traffickersgoing-unpunished-in-canada-experts-say-1.2584944).

Ogrodnik, Lucie. 2010. "Towards the Development of a National Data Collection Framework to Measure Trafficking in Persons." Crime and Justice Research Paper Series, Catalogue no. 85-561-M, No. 21. Statistics Canada. Retrieved January 2018 (http://www.statcan.gc.ca/pub/85-561-m/2010021/partpartie1-eng.htm).

Oxman-Martinez, Jacqueline, Marie Lacroix, and Jill Hanley. 2005. "Victims of Trafficking in Persons: Perspectives from the Canadian Community Sector. Report Prepared for the Department of Justice." Retrieved January 2018 (http://www.justice.gc.ca/eng/rp-pr/cj-jp/tp/rr06_3/rr06_3.pdf).

Perrin, Benjamin. 2010a. Invisible Chains: Canada's Underground World of Human Trafficking. Toronto: Penguin Group.

Perrin, Benjamin. 2010b. "Trafficking in Persons and Transit Countries: A Canada-U.S. Case Study in Global Perspective: Metropolis British Columbia Working Paper No. 10-05.” Retrieved January 2018 (https://papers.ssrn.com/sol3/papers.cfm?abstract_id=1611278).

Quayson, Ato and Antonela Arhin (editors). 2012. Labour Migration, Human Trafficking and Multinational Corporations: The Commodification of Illicit Flows (Routledge Transnational Crime and Corruption). New York: Routledge.

Royal Canadian Mounted Police (RCMP). 2010. "Human Trafficking in Canada: March 2010 Unclassified.” Ottawa: RCMP Criminal Intelligence. Retrieved January 2018 (http://publications.gc.ca/ collections/collection_2011/grc-rcmp/PS64-78-2010-eng.pdf).

Royal Canadian Mounted Police (RCMP). 2014. "Frequently Asked Questions on Human Trafficking: What is the Scope of Human Trafficking in Canada and Internationally?" Retrieved January 2018 (http://www.rcmp-grc.gc.ca/ht-tp/q-a-trafficking-traite-eng.htm\#q3).

Salt, John and Jennifer Hogarth. 2000. "Migrant Trafficking and Human Smuggling in Europe: A Review of the Evidence." In Migrant Trafficking and Human Smuggling in Europe: A Review of the Evidence with Case Studies from Hungary, Poland and Ukraine, edited by Frank Laczko and David Thompson. Geneva: International Organization for Migration.

Sanghera, Jyoti. 2005. "Unpacking the Trafficking Discourse." Pp. 3-24 in Trafficking and Prostitution Reconsidered: New Perspectives on Migration, Sex Work, and Human Rights, edited by Kamala Kempadoo, Jyoti Sanghera and Bandana Pattanaik. Boulder, CO: Paradigm.

Savona, Ernesto U. and Sonia Stefanizzi (editors). 2010. Measuring Human Trafficking: Complexities and Pitfalls. New York: Springer-Verlag.

Segrave, Marie, Sanja Milivojevic, and Sharon Pickering. 2009. Sex Trafficking: International Context and Response. London: Willan Publishing.

Sethi, Anupriya. 2007. "Domestic Sex Trafficking of Aboriginal Girls in Canada: Issues and Implications." First Peoples Child and Family Review 3(3):57-71.

Shelley, Louise. 2010. Human Trafficking: Global Perspective. New York: Cambridge University Press.

Sikka, Anette. 2009. "Trafficking of Aboriginal Women and Girls in Canada. Publications." Retrieved January 2018 (http://iog.ca/publications/trafficking-of-aboriginal-women-and-girls-in-canada/).

Thompson, Suzy. 2012. "Human Trafficking Affects Foreign Workers." Fast Forward Weekly, 29th March 2012. Retrieved January 2018 (http://www.migrantworkersrights.net/en/resources/human-traffickingaffects-foreign-workers).

United Nations. 2000. "Protocol to Prevent, Suppress and Punish Trafficking in Persons, Especially Women and Children, Supplementing the United Nations Convention against Transnational Organized Crime, 15 November 2000, 2237 UNTS 319 (entered into force 25 December 2003) [Palermo Protocol]." Retrieved January 2018 (http://www.ohchr.org/Documents/ProfessionalInterest/ProtocolonTrafficking.pdf). 
United Nations. n.d. "Universal Declaration of Human Rights, GA Res 217(III), UNGAOR, 3d Sess, Supp No 13, UN Doc A/810 (1948) 71." Retrieved January 2018 (http://www.un.org/en/documents/udhr/).

United Nations Office on Drugs and Crime (UNODC). 2011. "Case Law Database: Domotor et al." Retrieved December 2017 (http://www.unodc.org/cld/en/case-law/can/2011/domotor_et_al.html).

United States Department of State. 2012. “Trafficking in Persons Report 2012." Retrieved January 2018 (http://www.state.gov/j/tip/rls/tiprpt/2012/).

United States Government Accountability Office. 2007. "Human Trafficking: A Strategic Framework Could Help Enhance the Interagency Collaboration Needed to Effectively Combat Trafficking Crimes." July 2007. Retrieved January 2018 (https://www.gao.gov/assets/270/264645.pdf).

\section{Legislation}

Bill C-310, An Act to amend the Criminal Code (trafficking in persons), 1st Sess, 41st Parl, 2004.

Criminal Code, RSC 1985, c C-46.

Immigration and Refugee Protection Act, SC 2001, c 27.

\section{TRANSLATED ABSTRACTS}

\section{Sinopsis}

A pesar de la creciente conciencia sobre la trata de personas en Canadá (e internacionalmente), existe un conocimiento limitado sobre cómo las comunidades locales están respondiendo a las experiencias de las víctimas de la trata. Al centrarse en el caso de las respuestas de lucha contra la trata de personas en una ciudad importante del oeste de Canadá, este proyecto representa el primer intento canadiense de documentar cómo un importante centro urbano se ocupa de la trata de personas. El proyecto exploratorio encuestó a 53 personas que representaban a agencias involucradas en la respuesta de lucha contra la trata de personas, que en diversas capacidades prestan servicios a personas víctimas de la trata. Sobre la base de los resultados de la encuesta, también se llevaron a cabo cinco discusiones de grupos focales. El artículo sugiere que, si bien un marco de justicia penal es importante para abordar la trata de personas, las estrategias locales se beneficiarán de un énfasis en la colaboración intersectorial que enfatiza los derechos de las víctimas de trata por encima de las necesidades de la aplicación de la ley. Implicaciones para las respuestas (inter) nacionales son también presentadas.

Palabras clave: trata de personas; lucha contra la trata; explotación; sistema de justicia penal; asistencia a las víctimas

\section{Résumé}

Malgré une sensibilisation accrue sur le trafic des personnes au Canada (et à l'étranger), les connaissances sur la façon dans laquelle les collectivités locales répondent aux expériences des victimes de ce trafic sont limitées.

En mettant l'accent sur le cas des interventions de lutte contre le trafic dans une grande ville de l'Ouest canadien, ce projet représente la première tentative canadienne de traiter ce probleme dans un grand centre urbain.

Cet projet a interrogé 53 organismes impliqués dans la lutte contre ce trafic, qui, à divers titres, aident les personnes victimes de la traite. Sur la base des résultats de l'enquête, cinq groupes de discussion ont également été menés. 
L'article suggère que, bien qu'un cadre de justice pénale soit important pour lutter contre la traite des êtres humains, les stratégies des entités locales auraientt besoin d'une collaboration intersectorielle qui mettrait l'accent sur les droits des personnes victimes de trafic plutôt que sur les besoins des forces de l'ordre. Les implications pour les réponses (inter) nationales sont également présentées.

Mots-clés: traite des êtres humains; lutte contre la traite; exploitation; système de justice pénale; assistance aux victims

\begin{abstract}
摘要
尽管人们越来越意识到加拿大 (以及国际上) 的贩卖人口活动，但对于当地社区如 何应对被贩运者的经验知之甚少。通过关注加拿大西部一个主要城市的打击拐卖案 件, 这个项目是加拿大第一次记录主要城市中心如何处理人口贩运的企图。这个探 索性项目调查了53个参与打击贩运人口活动的机构，这些机构以不同的身份服务于 贩运受害者。根据调查结果, 还进行了五次焦点小组讨论。文章指出, 虽然刑事司 法框架对于解决人口贩运问题非常重要，但地方战略将受益于强调跨部门合作，强 调被贩运者超出执法需要的权利。还介绍了国家间相互作用的意义。
\end{abstract}

\title{
关键词: 贩卖人口; 反贩运; 剥削; 刑事司法制度; 受害者援助
}

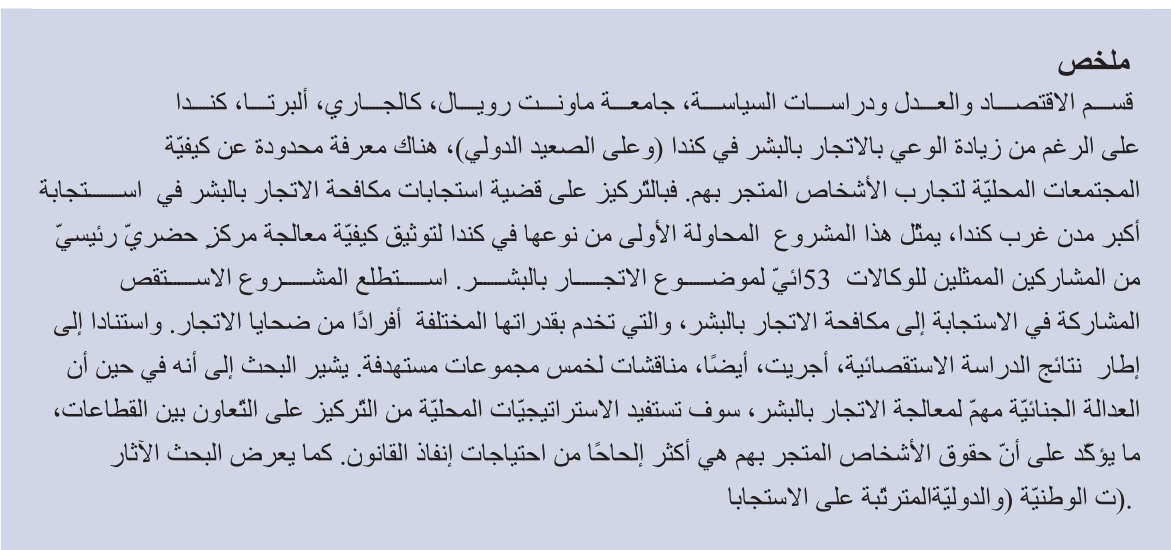

الكلمات الرئيسيّة: الاتجار بالبشر، مكافحة الاتجار ، الاستغلال، نظام العدالة الجنائبّة، مساعدة الضتحايا.

John Winterdyk is a Professor of Criminology and has published some 30 academic books including the volume co-edited with Benjamin Perrin and Philip Reichel entitled Human Trafficking: Exploring the International Nature, Concerns, and Complexities (2012, CRC Press). He is currently co-working editing a major reference work on human trafficking for Palgrave.

Cite this article: Winterdyk, J. 2017. Combating Human Trafficking at the Local Level: Better Informing (Inter)national Action Plans. International Annals of Criminology 55: 220-236, doi:10.1017/cri.2017.14 